\title{
PENGEMBANGAN KREATIVITAS ANAK USIA 5-6 TAHUN MELALUI MEDIA GERABAH
}

\author{
Ulfa $^{\text {a, } 1, ~ W i n a r t i ~}{ }^{\text {b, }, ~}$ \\ a,b Universitas NU Sunan Giri Bojonegoro, Indonesia \\ ${ }^{1}$ ulfa@sunan-giri.ac.id, ${ }^{2}$ winarti@gmail.com
}

\section{Informasi artikel \\ Received : \\ September 6, 2021. \\ Revised : \\ September 13, 2021. \\ Publish : \\ September 23, 2021.}

Kata kunci:

Kreativitas,

Anak usia 5-6;

Media gerabah;

\section{Keywords:}

Creativity;

Children Age 5-6;

Pottery Media;

\begin{abstract}
ABSTRAK
Tujuan penelitian ini untuk mengetahui kreativitas anak melalui media gerabah. peneliti mengambil tindakan dalam upaya meningkatkan kemampuan kreativitas anak melalui metode bermain dengan bahan alam tanah liat. Peneliti mengambil bahan alam tanah liat sebagai media bermain karena tanah liat aman bagi anak, mudah didapatkan, tidak mencemari lingkungan, dan dari media tanah liat ini dapat dihasilkan suatu produk seperti gerabah (berbagai macam peralatan rumah tangga, celengan, pot bunga) genting dan batu bata. Sedangkan ruang lingkup pelenitian ini dibatasi hanya pada pengaruh media gerabah terhadap pengembangan kreatifitas anak usia 5-6 tahun di TK Dharma Wanita Ngumpakdalem. Pendekatan yang digunakan dalam penelitian ini adalah pendekatan kualitatif. Sedangkat jenis penelitian yang akan digunakan oleh peneliti adalah penelitian deskriptif. Adapun Teknik pengumpulan data yang digunakan peneliti adalah dengan menggunakan Observasi, Diskusi dan Dokumentasi. Hasil penelitian kreativitas anak di kelas B TK Dharma Wanita Ngumpakdalem menunjukkan pengembangan yang baik, hal ini terbukti dari keseluruhan peserta didik yang mampu mengikuti kegiatan tersebut adalah 100\% (15 anak). Selain itu terlihat dari semangat, minat, dan antusias peserta didik dalam melakukan kegiatan bermain tanah liat untuk membuat gerabah
\end{abstract}

ABSTRACT
The purpose of this study was to determine the creativity of children
through pottery media. Researchers take action in an effort to improve
children's creative abilities through the method of playing with natural
materials of clay. Researchers took natural clay as a playing medium
because clay is safe for children, easy to obtain, does not pollute the
environment, and from this clay media can produce products such as
pottery (various kinds of household utensils, piggy banks, flower pots),
tiles and stones. brick. Meanwhile, the scope of this research is limited to
the influence of pottery media on the creative development of children
aged 5-6 years in Dharma Wanita Ngumpakdalem Kindergarten. The
approach used in this study is a qualitative approach. Meanwhile, the type
of research that will be used by researchers is descriptive research. The
data collection technique used by researchers is to use observation,
discussion and documentation. The results of the research on the
creativity of children in class B of Dharma Wanita Numpakdalem
Kindergarten showed good development, this was evident from the total
number of students who were able to participate in these activities were
$100 \%$ (15 children). Besides that, it can be seen from the enthusiasm,
interest, and enthusiasm of students in playing clay activities to make
pottery

This work is licensed under a Creative Commons Attribution-ShareAlike 4.0 International License. Allows readers to read, download, copy, distribute, print, search, or link to the full texts of its articles and allow readers to use them for any other lawful purpose. 


\section{PENDAHULUAN}

Pendidikan anak usia dini di Indonesia merupakan hal penting dan menjadi perhatian pemerintah karena dapat membantu kesiapan bagi anak- anak sebelum memasuki pendidikan lebih lanjut. Hal ini dapat kita lihat dalam UU. No 20 Tahun 2003 tentang sistem pendidikan nasional pasal 1 butir 14 yang bunyinya: "Pendidikan Anak Usia Dini adalah suatu upaya pembinaan yang ditujukan bagi anak sejak ia lahir sampai dengan usia 6 tahun yang dilakukan melalui pemberian rangsangan pendidikan untuk membantu pertumbuhan dan perkembangan jasmani dan rohani agar anak memiliki kesiapan dalam memasuki pendidikan lebih lanjut". Direktorat PAUD Depdiknas menyatakan bahwa PAUD adalah suatu proses pembinaan tumbuh kembang anak usia lahir hingga enam tahun secara menyeluruh, yang mencakup aspek fisik, dan nonfisik, dengan memberikan rangsangan bagi perkembangan jasmani, moral spiritual, motorik, emosional, dan sosial yang tepat dan benar agar anak dapat tumbuh dan berkembang secara optimal.

Sedangkan menurut (Susanto, 2011) menjelaskan bahwa pendidikan anak usia dini adalah pendidikan yang ditujukan bagi anak-anak berusia pra sekolah dengan tujuan agar anak dapat mengembangkan potensinya sejak dini sehingga mereka dapat berkembang secara wajar sebagai anak sesuai dengan tingkat usia dan tugas perkembangannya. Berdasarkan pengertian di atas, pendidik adalah seseorang yang bertanggung jawab dalam pembinaan dan pemberian rangsangan kepada anak didik untuk membantu pertumbuhan dan perkembangan anak agar anak siap memasuki jenjang pendidikan selanjutnya. (Menurut Sujiono, 2010) setiap anak memiliki kemampuan yang berbeda-beda dengan anak lainnya dan salah satu kemampuan yang dimiliki oleh anak adalah kemampuan kreativitas. Menurut (Angelou dalam Sujiono, 2011) bahwa kreativitas ditandai dengan adanya kemampuan untuk menciptakan, mengadakan, menemukan suatu bentuk baru dan atau untuk menghasilkan sesuatu melalui keterampilan imajinatif.

Pada usia ini anak mulai memahami pengalaman yang telah diperoleh. Dengan meningkatnya daya ingat, anak mampu berpikir sebelum bertindak dan mengembangkan kemampuan bahasa selain bekomunikasi dengan daya imajinasinya. Sedangkan cara yang bisa dilakukan untuk mengembangkan 
kemampuan anak pada usia ini diantaranya yaitu memberikan mainan yang dapat melatih daya kreativitasnya. Memberikan pengertian waktu, tentang "dulu", "nanti", dan "sekarang". Serta memberikan kesempatan bersosialisasi dengan lingkungan sekitar (Rismawati, 2012).

Anak usia dini pada dasarnya memiliki potensi kreatif namun demikian potensi yang dimiliki anak masih perlu dikembangkan. Kreativitas anak perlu di rangsang sejak dini karena pada usia ini merupakan awal dari kehidupan dan pada usia dini juga individu sedang menjalani suatu proses pertumbuhan dan perkembangan yang sangat pesat. Mengingat pentingnya mengembangkan kreativitas anak sejak usia dini maka anak perlu diberi kesempatan dalam mengungkapkan gagasan atau ide-ide yang ada dalam pikirannya. Hal ini perlu dirangsang oleh lingkungan sekolah maupun lingkungan keluarga dan juga membutuhkan pengembangan-pengembangan yang tepat dari para pendidik anak usia dini agar memperhatikan perkembangan kreativitas anak sejak dini dengan banyak memberikan kesempatan anak untuk bermain.

Perkembangan kreativitas saat ini semakin berkurang, hal ini disebabkan dengan berbagai macam fakta di lapangan yang masih menggunakan cara-cara yang menekankan pada pengembangan kecerdasan akademik sehingga pengembangan kreativitas kurang diperhatikan. Proses pembelajaran yang bersifat akademik atau yang lebih menekankan pada kecerdasan akademik dapat memadamkan kreativitas anak karena situasi dan kondisi pada saat pembelajaran tidak mendukung bagi peningkatan kreativitas anak. Dampaknya proses pembelajaran menjadi sesuatu yang membosankan bagi anak, maka dengan itu perlu adanya upaya yang dapat mengembangkan kreativitas anak. Proses pengembangan kreativitas anak tidak terlepas dari komponen-komponen pembelajaran yang mendukung dalam suatu pembelajaran diantaranya: guru, media pembelajaran, metode pembelajaran, sumber belajar, fasilitas pembelajaran, dan lain sebagainya.

Berdasarkan uraian di atas untuk menunjang hal tersebut maka guru sebagai fasilitator harus memfasilitasi peserta didik dengan berbagai keterampilan untuk membangkitkan semangat anak dalam mengikuti proses pembelajaran. Guru dituntut untuk mengembangkan model-model pembelajaran yang dapat membangkitkan dan memotivasi anak untuk belajar dengan aktif dan kreatif. Selain 
itu juga diperlukan suatu media yang menarik dan berguna sesuai dengan karakteristik perkembangan anak. Penggunaan media dalam proses pembelajaran sangat penting dalam mendukung berhasil tidaknya proses kegiatan belajar mengajar yang efektif dan efisien di TK. Banyak media yang dapat digunakan untuk mendukung proses pengembangan kreativitas anak salah satunya yaitu media gerabah. Media gerabah dapat merangsang anak untuk menciptakan sesuatu yang baru, hal ini tergantung pada kemampuan anak untuk mendapatkan pengetahuan yang sudah ia terima kemudian ia tuangkan dalam gerabah tersebut sehingga anak dapat menciptakan sesuatu yang baru.

Berdasarkan dari hasil observasi yang telah peneliti lakukan pada hari Rabu tanggal 12 Desember 2018 di TK Dharma Wanita Ngumpakdalem, menunjukan ditemukannya beberapa permasalahan yang muncul dalam perkembangan kreativitas anak. Hal ini disebabkan karena kurangnya pembelajaran yang aktif dan kreatif serta media yang kurang menarik dan bervariatif, Sehingga anak cepat merasa bosan. Misalnya dalam kegiatan membuat suatu bentuk benda. Dalam hal ini guru menuntut anak untuk membuat suatu benda sesuai contoh yang telah di buat oleh guru, tanpa memberikan kesempatan bagi anak untuk membuat menurut kreasi dan imajinasi mereka, ada pula anak yang segera mengatakan "aku tidak bisa" ketika anak diminta untuk melakukan kegiatan pembelajaran dalam hal kreativitas.

Melihat berbagai faktor yang dapat menjadi kendala dalam hal pengembangan kreativitas anak, peneliti mencoba mengambil tindakan dalam upaya meningkatkan kemampuan kreativitas anak melalui metode bermain dengan bahan alam tanah liat. Peneliti mengambil bahan alam tanah liat sebagai media bermain karena tanah liat aman bagi anak, mudah didapatkan, tidak mencemari lingkungan, dan dari media tanah liat ini dapat dihasilkan suatu produk seperti gerabah (berbagai macam peralatan rumah tangga, celengan, pot bunga) genting dan batu bata. Berdasarkan uraian diatas peneliti mengambil judul "Pengembangan Kreativitas Anak Usia 5-6 Tahun Melalui Media Gerabah".

\section{METODE}

Pendekatan yang digunakan dalam penelitian ini adalah pendekatan kualitatif (qualitatif research). Hal ini, dikarenakan penelitian ini berusaha memaparkan 
realitas yang ada tanpa memerlukan data yang berupa angka-angka (kuantitatif) dan berusaha menggambaran suatu keadaan beserta segala aspeknya dalam rangka memberikan informasi sejelas-jelasnya kepada peneliti, data tersebut mungkin berasal dari naskah wawancara, catatan lapangan, dokumen pribadi, catatan memo, dan dokumen resmi lainnya sehingga pendekatan penelitian yang dimaksudkan untuk mengungkapkan gejala seara holistik-konstekstual melalui pengumpulan data dengan latar alami dengan memanfaatkan diri peneliti sebagai instrumen kunci.

Jenis penelitian yang digunakan adalah penelitian lapangan yaitu penelitian yang dilakukan secara intensif, terinci dan mendalam terhadap suatu organisasi, lembaga atau gejala tertentu. Lokasi penelitian ini di TK Dharma Wanita Ngumpakdalem Kecamatan Dander Kabupaten Bojonegoro. Sample penelitian Ini anak Usia 5-6 tahun TK Dharma Wanita Ngumpakdalem. Tehnik dan alat pengumpulan data dalam penelitian ini adalah dengan observasi, diskusi dan dokumentasi. Teknik pengecekan keabsahan yang digunakan dalam penelitian yaitu perpanjangan keikutsertaan, ketekunan observasi, trianggulasi

\section{PEMBAHASAN}

Berdasarkan hasil penelitian TK Dharma Wanita Ngumpakdalem dapat diuraikan bahwa penggunaan media gerabah dalam meningkatkan kreativitas anak usia dini sebagai berikut :

a. Mempersiapkan media pembelajaran yang akan disampaikan.

Sumber belajar merupakan sesuatu yang harus ada dalam setiap pembelajaran, oleh karena itu, sebelum pelaksanaan kegiatan, sumber belajar yang dibutuhkan harus disiapkan terlebih dahulu. Berdasarkan hasil observasi penulis dilapangan, tahap awal yang dilakukan guru adalah menyiapkan media pembelajaran atau bahan ajar yang akan disampaikan kepada anak. Mempersiapkan bahan baku, bahan campuran, dan alat pengolahan bahan. Dalam tahap awal ini guru terlebih dahulu memberikan contoh hasil kreativitas gerabah. Tujuannya agar anak tertarik untuk melakukan kegiatan pembelajaran. 
Hal ini senada dengan hasil wawancara penulis kepada salah seorang guru di TK Dharma Wanita Ngumpakdalem, yang bernama Lilik Nur Maslihah, S.Pd.I, bahwasanya kegiatan awal ini guru terlebih dahulu menetapkan dan menyediakan bahan ajar yang akan di gunakan agar guru lebih siap dalam memberikan materi pada saat pembelajaran.

b. Menjelaskan media yang di kerjakan

Sebelum anak-anak mengerjakan media yang telah ditetapkan, guru harus menjelaskan secara rinci tentang media yang akan dikerjakan. Hal ini penting dilakukan agar pada saat anak mengerjakan, anak lebih mengerti prosedur kerja yang akan dilakukan. Berdasarkan hasil wawancara penulis dengan salah satu guru di TK Dharma Wanita Ngumpakdalem yang bernama Yuliati,S.Pd, bahwasanya pada tahap ini guru mengajarkan cara kerja media gerabah, memperkenalkan alat dan bahan, serta menyebutkan warna

c. Mengatur Pembagian kelompok

Membagi anak ke dalam beberapa kelompok kerja, sangat mempengaruhi kelancaran pelaksanaan kegiatan. Pengelompokan anak juga harus memperhatikan kepribadian masing-masing anak, dalam artian kelompok siswa sejenis dalam satu kelompok. Dengan demikian mereka dapat saling bekerja sama. Kerja sama antar kelompok sangat penting artinya dalam pembelajaran.

Berdasarkan hasil wawancara penulis kepada salah seorang guru di TK Dharma Wanita Ngumpakdalem, yang bernama Lilik Nur Maslihah,S.Pd.I, Pada tahap ini guru membagi anak-anak menjadi 3 kelompok yang terdiri dari 5 orang perkelompok, tujuannya agar anak fokus, tidak berpindah-pindah tempat, dan bisa menyesuaikan diri dalam melakukan kegiatan bersama kelompoknya, melatih agar anak mau berbagi dengan temannya.

\section{Analisis Data}

a. Pengambilan data pretest

Pengambilan data pretest dilakukan pada subyek penelitian sebanyak satu kali. Pelaksanaan pretest dilaksanakan pada tanggal 6 Juni 2019, mulai pukul 08.00 sampai dengan 09.00, selama 60 menit. Tes tersebut digunakan untuk memperoleh data awal mengenai kreatifitas anak dengan menggunakan 
media selain gerabah. Berdasarkan observasi yang dilakukan penulis mengenai kreativitas anak usia dini di kelas B TK Dharma Wanita Ngumpakdalem melalui media selain gerabah. maka penulis menyajikan data sebagai berikut:

\section{Tabel Observasi Pra Penelitian Kemampuan Kreativitas Anak Didik di kelas B usia 5-6 TK Dharma Wanita Ngumpakdalem}

\begin{tabular}{|c|l|c|c|c|c|c|c|}
\hline \multirow{2}{*}{ No } & \multirow{2}{*}{$\begin{array}{c}\text { Nama Anak } \\
\text { Didik }\end{array}$} & \multicolumn{5}{|c|}{ Indikator } & Ket \\
\cline { 3 - 9 } & & 1 & 2 & 3 & 4 & 5 & \\
\hline 1 & Alfi & BB & MB & BB & BB & MB & BB \\
\hline 2 & Anggita & MB & BB & MB & BB & BB & MB \\
\hline 3 & Eliana & BB & BB & MB & BB & BB & BB \\
\hline 4 & Fitria & BSH & MB & BSH & MB & BB & BSH \\
\hline 5 & Jibrila & MB & BB & MB & BB & MB & BB \\
\hline 6 & Arka'an & BB & BB & BB & BB & MB & BB \\
\hline 7 & Eza & BSH & MB & BSH & BS & MB & BSH \\
\hline 8 & Ibnu & BB & MB & BB & BB & BB & BB \\
\hline 9 & Rizky & MB & BB & MB & BB & BB & BB \\
\hline 10 & Rifa'ul & BB & BB & MB & BB & MB & BB \\
\hline 11 & Jamaluddin & BSH & MB & BSH & BSH & MB & BSH \\
\hline 12 & Najib & MB & MB & BB & BSB & BB & MB \\
\hline 13 & Reza & MB & BSB & BB & MB & MB & MB \\
\hline 14 & Safira & MB & BB & BSB & BB & BB & BB \\
\hline 15 & Mahika & BSB & MB & BSB & MB & MB & MB \\
\hline
\end{tabular}

Sumber : hasil observasi pra penelitian di TK Dharma Wanita Ngumpakdalem

Keterangan indikator pencapaian kreativitas :

1. Kemampuan anak untuk mengeluarkan ide baru

2. Gagasan atau produk baru

3. Kombinasi baru berdasarkan data yang ada

4. Idealis dalam berkarya tidak sama dengan hasil teman-teman nya

5. Menunjukkan sikap kemandirian

Berdasarkan tabel data awal hasil prasurvey diatas menunjukkan bahwa tingkat kreatifitas anak usia 5-6 tahun di TK Dharma Wanita Ngumpakdalem dengan kegiatan pembelajaran melalui berbagai media selain media gerabah belum berkembang secara optimal.

b. Pemberian perlakuan (Treatment)

Perlakuan berlangsung selama 4 hari, yaitu pada tanggal 10-11 Juni dan 17-18 Juni 2019. Pelaksanaan treatment dilakukan mulai pukul 08.00 sampai dengan 09.00, berlangsung selama 60 menit. Tes tersebut digunakan untuk memperoleh data anak 
pada saat diberikan pembelajaran tentang pengembangan kreatifitas melalui media gerabah.

Di hari pertama peneliti mengamati anak di kelas B TK Dharma Wanita Ngumpakdalem masih banyak kreativitas anak yang belum berkembang, anakanak cenderung sibuk dengan kegiatan masing-masing, malas, dan sebagian mengeluh capek. Di hari kedua peneliti mengamati ada beberapa anak yang kemampuan kreativitasnya dengan kegiatan membuat bentuk melalui media gerabah mulai meningkat, di hari berikutnya ada beberapa anak yang mulai meningkat serta banyak yang berkembang sesuai harapan, dan dihari berikutnya pun sudah banyak anak yang mulai berkembang, berkembang sesuai harapan, bahkan berkembang sangat baik. Setelah melakukan upaya yang maksimal dari kedua guru di kelas B, dengan berdasarkan langkah-langkah serta indikator pencapaian yang sesuai dengan tingkat kreativitas anak usia dini, maka penulis mendapati hasil observasi data akhir sebagai berikut :

Tabel Observasi Akhir Kemampuan Kreativitas Anak kelas B usia 56 di TK Dharma Wanita Ngumpakdalem

\begin{tabular}{|c|c|r|r|r|r|r|r|}
\hline \multirow{2}{*}{ No } & Nama Anak Didik & \multicolumn{5}{|c|}{ Indikator } & Ket \\
\cline { 3 - 8 } & & 1 & 2 & 3 & 4 & 5 & \\
\hline 1 & Alfi & BSH & BSB & BSB & BSH & BSH & BSB \\
\hline 2 & Anggita & BSH & BSH & MB & BSH & BSH & BSH \\
\hline 3 & Eliana & MB & BB & MB & BSH & BSH & MB \\
\hline 4 & Fitria & BSB & BSB & BSB & BSH & BSH & BSB \\
\hline 5 & Jibrila & BSH & MB & MB & BSH & MB & MB \\
\hline 6 & Arka'an & BSB & BSH & BSB & BSH & MB & BSH \\
\hline 7 & Eza & BSB & BSB & BSB & BSH & MB & BSB \\
\hline 8 & Ibnu & BSH & BSH & MB & BSH & BSH & MB \\
\hline 9 & Rizky & BSH & BSH & BSH & BSH & MB & BSH \\
\hline 10 & Rifa'ul & BSB & BSB & BSB & BSH & MB & BSB \\
\hline 11 & Jamaluddin & BSB & BSB & BSB & BSH & MB & BSB \\
\hline 12 & Najib & BSB & BSH & BSB & BSH & MB & BSH \\
\hline 13 & Reza & BSH & BSB & BSH & BSH & BSH & BSH \\
\hline 14 & Safira & BSB & BSB & BSH & BSH & MB & BSH \\
\hline 15 & Mahika & BSB & BSH & BSB & BSH & MB & MB \\
\hline
\end{tabular}

Sumber : hasil observasi penelitian di TK Dharma Wanita Ngumpakdalem.

Keterangan indikator pencapaian kreativitas :

1. Kemampuan anak untuk mengeluarkan ide baru

2. Gagasan atau produk baru

3. Kombinasi baru berdasarkan data yang ada 
4. Idealis dalam berkarya tidak sama dengan hasil teman-teman nya

5. Menunjukkan sikap kemandirian

Berdasarkan hasil wawancara, observasi dan dokumentasi, maka hasil akhir pengembangan kreativitas anak usia dini melalui media gerabah di TK Dharma Wanita Ngumpakdalem, sebagai Berikut :

a. Perkembangan awal Kreativitas Ananda Alfi ini belum berkembang. Berdasarkan hasil observasi yang dilakukan pada ananda yang ditandai dengan tingkat awal pencapaian indikator kreativitas nya kurang semangat.

Hasil wawancara yang diutarakan oleh ibu Yuliati bahwa ananda Alfi kurang bersemangat saat melakukan kegiatan bermain tanah liat untuk membuat gerabah dikarenakan ananda alfi memiliki sifat yanga agak malas sehinga sulit bagi Ananda Alfi untuk menyesuaikan dengan lingkungan termasuk ketika melakukan kegiatan tersebut.

Pada tahap ini guru selalu memberikan semangat dengan terus mengajak ananda alfi untuk berkemauan membuat prakarya dengan menggunakan tanah liat yaitu gerabah, sehingga Tingkat Akhir Pencapaian Kreativitas ananda Alfi mampu berkembang sesuai harapan. Ditandai dengan dengan besarnya semangat ananda saat melakukan kegiatan membuat bentuk piring dari tanah liat seperti yang dicontohkan oleh guru.

b. Perkembangan kreativitas ananda Anggita ini mulai berkembang. berdasarkan hasil observasi yang dilakukan pada ananda yang ditandai dengan tingkat awal pencapaian indikatornya, perkembangan kreativitasnya mulai baik. Pada tahap awal ini, ananda sudah mulai mampu meremas-remas tanah liat dan membuat bentuk dasar seperti membuat bulatan-bulatan. Hasil wawancara dengan Ibu Yuliati bahwa ananda Anggita mampu menyesuaikan diri dengan teman-teman sekitar maupun dengan guru sehingga ananda dengan mudah memahami pembelajaran yang diberikan guru. Ananda diberikan latihan, ternyata didapati bahwa ananda Anggita selalu antusias dalam mengikuti kegiatan sehingga pada tingkat pencapaian perkembangan kreativitas akhir ananda berkembang sesuai harapan.

c. Perkembangan kreativitas ananda Eliana ini mulai berkembang. pada awalnya belum berkembang dilihat dari pencapaian indikator kreativitasnya, setelah diobservasi sudah mulai berkembang dilihat dari kepandaian nya dalam 
kegiatan membuat bentuk gerabah dengan media tanah liat seperti yang dicontohkan oleh guru.

d. Perkembangan kreativitas ananda Fitria ini berkembang sangat baik. Pada awalnya masih kurang berkembang namun setelah diobservasi membuahkan hasil yang baik. Terlihat ketika dalam kegiatan kreatifitas membuat gerabah, dia cekatan dalam menggunakan jari-jarinya untuk

e. Perkembangan kreativitas ananda Jibrila mulai berkembang. Pada awalnya belum berkembang dilihat dari pencapaian indikator kreativitasnya, setelah diobservasi perkembangan kreativitasnya mulai berkembang. Dalam kegiatan kreatifitas gerabah ananda sudah pandai bermain sesuai dengan perintah guru tetapi belum mampu mengungkapkan ide baru sesuai imajinasinya.

f. Perkembangan kreativitas ananda Arka'an berkembang sesuai harapan. Pada awalnya belum berkembang dilihat dari pencapaian indikator kreativitasnya, setelah diobservasi pengembangan kreativitas berkembang sesuai harapan karena pada setiap indikator ananda Arka'an dapat melakukanya dengan baik.

g. Perkembangan kreativitas ananda Eza berkembang sangat baik. Pada awalnya kurang berkembang dilihat dari pencapaian indikator kreativitasnya, setelah diobservasi pengembangan kreativitas berkembang sangat baik terlihat dari pandainya membuat berbagai bentuk gerabah dan mengeluarkan gagasan baru.

h. Perkembangan kreativitas ananda Ibnu ini mulai berkembang. pada awalnya kurang berkembang dilihat dari indikator pencapaianya karena ananda Indah cenderung sangat pemalu. Namun berkat bimbingan dan motivasi yang terus dilakukan guru Alhamdulillah ananda Ibnu sudah mulai berkembang. terlihat dari perkembangan yang baik pada indikator 1 dan 3 .

i. Perkembangan kreativitas ananda Rizky ini berkembang sesuai harapan. Pada awalnya belum berkembang dilihat dari indikator pencapaian kreativitasnya, setelah di observasi Alhamdulillah ditandai dengan besarnya semangat ananda saat melakukan kegiatan membuat gerabah, jari nya dengan lincah membuat bentuk gelas. 
j. Perkembangan kreativitas ananda Rifa'ul ini berkembang sangat baik. Terlihat ketika ananda Rifa'ul melakukan kegiatan bermain tanah liat untuk membuat gerabah. Ananda bisa mengembangkan daya imajinasinya dengan baik dan mengeluarkan ide-ide baru, sehingga bisa membuat bentuk lain dari yang dicontohkan oleh guru seperti membuat peralatan makan yang lain yaitu sendok dan garpu.

k. Perkembangan kreativitas ananda Jamaluddin ini berkembang dengan baik. Berdasarkan observasi yang dilakukan pada ananda ditandai dengan besarnya semangat ananda saat melakukan kegiatan bermain tanah liat untuk membuat gerabah. Ananda menunjukkan kemandirian saat bermain dan bisa bekerja sama dengan temannya.

1. Perkembangan kreativitas ananda Najib ini berkembang sesuai harapan. Karena setelah di observasi melalui kegiatan bermain membuat gerabah, Ananda dapat menunjukkan keaktifan dan antusias nya dalam bermain. Padahal sebelumnya apabila dalam kegiatan yang sejenis seperti membuat bentuk dari kertas lipat, Ananda terkesan malas dan tidak bersemangat.

m. Perkembangan kreativitas ananda Reza berkembang sesuai harapan. Pada awalnya belum berkembang dilihat dari pencapaian indikator kreativitasnya, setelah diobservasi pengembangan kreativitas berkembang sesuai harapan karena pada setiap indikator ananda Reza dapat melakukanya degan baik

n. Perkembangan kreativitas ananda Safira berkembang sesuai harapan. Pada awalnya belum berkembang dilihat dari pencapaian indikator kreativitasnya, setelah diobservasi pengembangan kreativitas berkembang sesuai harapan karena pada setiap indikator ananda Safira dapat melakukanya degan baik.

o. Perkembangan kreativitas ananda Mahika ini mulai berkembang. pada awalnya kurang berkembang dilihat dari indikator pencapaianya karena ananda Mahika cenderung sangat pendiam. Namun berkat bimbingan dan motivasi yang terus dilakukan guru Alhamdulillah ananda Mahika sudah mulai berkembang. terlihat dari perkembangan yang baik pada indikator 1 dan 5 .

Berdasarkan hasil observasi diatas, dapat disimpulkan bahwa guru berperan aktif dalam setiap perkembangan anak usia dini khususnya dalam kegiatan bermain tanah liat untuk membuat gerabah. Dan guru harus selalu menyiapkan bahan ajar yang akan 
diberikan kepada anak, memberikan materi atau contoh permainan, serta melakukan evaluasi. Dengan diterapkannya langkah-langah dalam mengembangkan kreativitas anak usia dini melalui media gerabah di kelas B Tk Dharma Wanita Ngumpakdalem diharapkan akan menunjukkan hasil yang optimal

Berdasarkan hasil observasi, wawancara, dan dokumentasi penulis diatas, dapat disimpulkan bahwa guru telah mengajarkan kegiatan untuk mengembangkan kreativitas anak usia dini melalui interaksi yang baik kepada anak dengan cara terlebih dulu mengarahkan anak tentang apa yang akan dilakukan sebelum memulai kegiatan, menjelaskan tentang bahan dan alat yang akan digunakan, menjelaskan tentang apa itu gerabah beserta contoh- contohnya dan kemudian memberikan contoh bagaimana cara bermain yang baik dan benar, serta memotivasi anak agar lebih antusias dan bersemangat saat bermain.

TK Dharma Wanita Ngumpakdalem tidak semata-mata mengajarkan anak untuk mengembangkan kreatifitas membuat bentuk hanya dengan media APE buatan pabrik saja seperti kertas lipat, lego dan balok, tetapi Guru juga berusaha menumbuhkan rasa cinta anak terhadap alam, salah satunya dengan bermain tanah liat untuk membuat gerabah. Melalui variasi cara mengajar ini, guru juga dapat menanamkan nilai-nilai positif kepada anak dengan mengajarkan kepada merkea untuk bersyukur dengan segala ciptaan Tuhan yang dapat dimanfaatkan untuk kepentingan manusia. Selain itu, variasi cara mengajar ini membuat anak tidak jenuh dengan kegiatan yang cenderung monoton.

Dapat penulis uraikan bahwa perkembangan kreativitas anak ini ditandai dengan meningkatnya pemahaman anak dalam proses bermain tanah liat untuk membuat gerabah. Selain itu penulis melihat adanya semangat peserta didik dalam melakukan kegiatan bermain tanah liat untuk membuat gerabah, dilihat dari minat peserta didik dalam bermain sangat antusias. Terlihat sebagian besar peserta didik sudah mulai mau mengikuti arahan guru, kreatif, mau menambahkan bentuk lain saat bermain, menunjukkan kemandirian saat bermain serta mulai bisa berkomunikasi dengan sesama teman.

Berdasarkan pengamatan yang dilakukan oleh penulis, peserta didik pada kelas B di TK Dharma Wanita Ngumpakdalem sebagian besar telah memahami apa itu gerabah, terlihat dari perkembangan kreatifitas peserta didik yang mengacu pada 
pedoman observasi yang dibuat oleh penulis. Seperti anak mampu mengeluarkan ide baru dan mengembangkan imajinasinya untuk membuat gerabah dengan bentuk lain selain dengan yang dicontohkan oleh guru misalnya mereka membuat mangkok yang ditambahkan dengan bentuk bulatan-bulatan dan memanjang. Setelah Guru menanyakan apa yang mereka buat, mereka menjawab bahwa itu semangkok bakso. Selain itu peserta didik sebagian besar dapat menciptakan karya baru tanpa meniru karya temannya yang lain. Sikap sosial mereka juga terbangun dengan baik saat bemain, ditandai dengan adanya saling membantu satu dengan yang lainnya.

Berdasarkan hasil wawancara bahwa dalam proses pembelajaran yang pertama kali disiapkan adalah bahan pembelajaran misalnya tanah liat, wadah untuk menampung dan air. Untuk lebih memudahkan pembelajaran ini lebih lanjut guru menjelaskan pembelajaran dengan cara praktek langsung, artinya dilakukan anak dengan didampingi oleh guru untuk mengarahkannya. Guru memberi arahan kepada anak agar mendapat hasil yang baik. Berdasarkan hasil wawancara menunjukkan adanya manfaat dan fungsi yang baik. Diantaranya selain dapat mengembangkan kreatifitas anak, bermain tanah liat. untuk membuat gerabah juga dapat meningkatkan kemampuan motorik halus anak. Karena ketika anak meremas-remas dan menekan tanah liat untuk membuat bentuk gerabah, otot-otot jari mereka akan terstimulasi dengan baik dan koordinasi antara mata dan tangan juga dapat berkembang dengan baik.

Berdasarkan uraian di atas dapat disimpulkan bahwa pembelajaran menggunakan media tanah liat untuk membuat gerabah dapat memberikan pengaruh baik terhadap pengembangan kreativitas anak sehingga semakin senang anak dalam bermain semakin baik pula pengembangan kreativitas nya. Pengembangan kreativitas anak di kelas B TK Dharma Wanita ngumpakdalem menunjukkan hasil pengembangan yang baik, hal ini terbukti dari keseluruhan peserta didik yang mampu mengikiti kegiatan tersebut adalah 100\% (15 anak). Selain itu terlihat dari semangat, minat, dan antusias peserta didik dalam melakukan kegiatan bermain tanah liat untuk membuat gerabah.

\section{KESIMPULAN}

kreativitas anak usia 5-6 Tahun di TK Dharma Wanita Ngumpakdalem dapat diukur dengan 5 indikator kreativitas yaitu :(1) Kemampuan anak untuk 
mengeluarkan ide baru, (2) Gagasan atau produk baru, (3)Kombinasi baru berdasarkan data yang ada, (4) Idealis dalam berkarya tidak sama dengan hasil teman-teman nya, (5) Menunjukkan sikap kemandirian. Hasil penelitian menunjukan kreativitas anak usia 5-6 Tahun di TK Dharma Wanita Ngumpakdalem tergolong bervariasi, ada beberapa dari mereka yang belum berkembang dan banyak pula yang mengalami pertkembanga pesat.

Pengembangan kreativitas anak di kelas B TK Dharma Wanita Ngumpakdalem melaui media gerabah menunjukkan hasil pengembangan yang baik, hal ini terbukti dari keseluruhan peserta didik yang mampu mengikuti kegiatan tersebut adalah 100\% (15 anak). Selain itu terlihat dari semangat, minat, dan antusias peserta didik dalam melakukan kegiatan bermain tanah liat untuk membuat gerabah.

\section{REFRENSI}

Arikunto, Suharsimi. 2006. Prosedur Penelitian: Suatu Pendekatan Praktek. Jakarta: Rineka Cipta.

Arsyad, Azhar. 2011. Media Pembelajaran. PT Rajagrafindo Persada, Jakarta.

Bambang, Sujiono. 2010. Bermain Kreatif Berbasis Kecerdasan Jamak. Jakarta :PT. Indeks.

Budiningsih, Asri. 2012. Belajar dan Pembelajaran. Jakarta : Rineka Cipta. Depdiknas. 2006. Pedoman Pembelajaran Di Taman Kanak-kanak. Jakarta: Depdiknas. Direktorat Jenderal Manajemen Pendidikan Dasar dan Menengah. Faturrohman, Pupuh. 2007. Strategi Belajar Mengajar. Bandung : PT Refika Aditama.

Hamalik, Oemar. 2008. Kurikulum Dan Pembelajaran. Jakarta : Bumi Aksara.

Iqbal, Hasan M. 2002. Pokok- Pokok Materi Metodologi Penelitian dan Aplikasi. Jakarta : Galia Indonesia.

Mardalis, 2003. Metode Penelitian Pendidikan Suatu Pendekatan Proposa. Jakarta : Bumi Aksara.

Moeloeng, Lexy J. 1996. Metodologi Penelitian Kualitatif. Bandung : Remaja Rosdakarya

Montolalu, dkk. 2009. Bermain dan Permainan. Anak. Jakarta : Universitas Terbuka.

Mulyasa. 2014. Manajemen PAUD. Bandung: PT Remaja Rosda Karya

Murniati, Endyah. 2012. Pendidikan dan Bimbingan Anak Kreatif. Yogyakarta : PT Pustaka Insan Madani.

Musbikin, Imam. 2010. Buku Pintar PAUD. Lakasana : Yogyakarta.

Nurani, Sujiono Yuliani dan Sujiono, 2010. Bermain Kreatif Berbasis Kecerdasan Jamak. Jakarta : PT. Indeks.

Patmonodewo,Soemarti. 2003 Pendidikan Anak Prasekolah. Jakarta:Rineka Cipta. Prasisti, Wiwin Dinar. 2008. Psikologi Anak Usia Dini. Bogor:PT Indeks Anggota IKPI. 
Priyadharma,Triguna. 2015. Kreativitas dan Strategi. Golden Trayon Pres : Jakarta.

Rachawati, Yeni. 2010. Strategi Pengembangan Kreativitas Pada Anak Usia Taman Kanak- Kanak. Jakarta : Kencana.

Rismawati. 2012. Menstimulasi Perkembangan Anak dengan Permainan. Yogyakarta : PT Pustaka Insan Madani.

Sugiyono, 2009. Metode Penelitian Pendidikan. Bandung : Alfabeta.

Sujiono, Yuliani Nurani. 2012. Konsep Dasar Pendidikan Anak Usia Dini. Jakarta Barat: PT. Indeks Permata Puri Media.

Susanto, Ahmad. 2011. Perkembangan Anak Usia Dini. Jakarta :Kencana Prenada Media Group.

Suyadi. 2012. Psikologi Belajar Anak Usia Dini. Yogyakarta : PT Pustaka Insan Madani. 